\title{
KEPASTIAN HUKUM SERTIFIKAT HAK MILIK ATAS TANAH DALAM HUKUM PERTANAHAN INDONESIA
}

\author{
Helena Sumiati ${ }^{1}$, Ardiansah $^{2}$, Bagio Kadaryanto ${ }^{3}$ \\ ${ }^{1}$ Program Studi Magister Ilmu Hukum Universitas Lancang Kuning, Pekanbaru, 28265 \\ E-mail: helenasumiatihs@gmail.com \\ ${ }^{2}$ Program Studi Magister Ilmu Hukum Universitas Lancang Kuning, Pekanbaru, 28265 \\ E-mail: ardiansyah2000@yahoo.com \\ ${ }^{3}$ Program Studi Magister Ilmu Hukum Universitas Lancang Kuning, Pekanbaru, 28265 \\ E-mail: bagio.kadaryanto@gmail.com
}

\begin{abstract}
Abstrak
Pasal 3 huruf a Peraturan Pemerintah Nomor 24 Tahun 1997 tentang Pendaftaran Tanah mengatakan untuk memberikan kepastian hukum dan perlindungan hukum kepada pemegang hak atas suatu bidang tanah, satuan rumah susun dan hak-hak lain yang terdaftar agar dengan mudah dapat membuktikan dirinya sebagai pemegang hak yang bersangkutan. Namun dalam perjalanan waktu keberadaan Peraturan Pendaftaran ini dianggap belum maksimal karena ada beberapa kendala diantaranya keterbatasan dana dan tenaga sehingga penguasaan tanah-tanah sebagian besar tidak didukung oleh alat pembuktian yang memadai. Selain itu Peraturan Pemerintah ini belum cukup memberikan kemungkinan untuk terlaksananya pendaftaran tanah dengan waktu yang singkat dan hasil yang memuaskan. Jenis penelitian yang digunakan dalam penulisan penelitian ini adalah penelitian hukum Normatif, yang membahas tentang kepastian hukum sertifikat hak milik atas tanah dalam hukum pertanahan Indonesia. Dari hasil penelitian dapat disimpulkan kepastian hukum sertifikat hak milik atas tanah adalah belum sesuai dengan kepastian hukum mengenai objek hak atas tanah, subjek hak atas tanah dan mengenai kepastian atas tanah dan dengan jaminan negara ini diberikan kepada pemilik atau pemegang sertifikat dapat diberikan karena tanahnya sudah terdaftar dalam sistem administrasi pertanahan negara. Idealnya kepemilikan tanah agar memiliki kepastian hukum yang sesuai adalah perlindungan bagi pemegang hak atas tanah yang secara yuridis formal merupakan hak bagi setiap warga negara Indonesia, namun demikian tindakan untuk menindak setiap pihak yang melakukan pendudukan atas tanah oleh pihak tertentu secara tidak sah harus dilakukan dengan hati-hati agar tidak menimbulkan konflik sosial, ataupun konflik antara warga dengan Pemerintah.
\end{abstract}

\section{Kata Kunci : Kepastian hukum, Sertifikat, Pertanahan}

\begin{abstract}
Article 3 letter a Government Regulation Number 24 of 1997 concerning Land Registration says to provide legal certainty and legal protection to rights holders of land parcels, apartment units and other registered rights so that they can easily prove themselves as holders of the rights concerned. . However, in the course of time, the existence of this Registration Regulation is considered to have not been optimal because there are several obstacles including limited funds and personnel so that control of land is largely not supported by adequate evidence. In addition, this Government Regulation is not sufficient to provide the possibility for the implementation of land registration in a short time and with satisfactory results. The type of research used in the writing of this research is Normative legal research, which discusses the legal certainty of land title certificates in Indonesian land law. From the results of the research, it can be concluded that the legal certainty of land title certificates is not in accordance with legal certainty regarding the object of land rights, the subject of land rights and regarding certainty over land and with this state guarantee given to the owner or certificate holder it can be given because the land is already registered. in the state land administration system. Ideally, land ownership in order to have appropriate legal certainty is protection for land rights holders which are legally formal rights for every Indonesian citizen, however actions to take action against any party who occupies land by certain parties illegally must be carried out with care. -be careful not to cause social conflict or conflict between citizens and the government.
\end{abstract}

Keywords: Legal certainty, Certificate, Land

\section{PENDAHULUAN}

Berbicara mengenai tanah, hal ini tidak terlepas dan erat kaitannya dengan hajat hidup orang banyak. Tanah merupakan sumber kehidupan dan merupakan harta kekayaan yang mempunyai nilai tinggi. Tanah juga merupakan sumber daya alam yang terpenting sekarang ini, di saat populasi manusia terus meningkat sementara luasnya tetap dan tidak bertambah. ${ }^{1}$ Undang-Undang Pokok Agraria (UUPA) adalah sebutan lain dari Undangundang Nomor 5 Tahun 1960 tentang

${ }^{1}$ A.P.Parlindungan, Pedoman Pelaksana UUPA dan Tatacara PPAT, (Bandung: Alumni Bandung, 1987), Hal. 51. 
Peraturan Dasar Pokok-pokok Agraria. Undang-undang ini disahkan dan diundangkan pada tanggal 24 September 1960 di Jakarta. $^{2}$ Tujuan dikeluarkannya UUPA adalah untuk mengakhiri dualisme hukum agraria di Indonesia pada saat itu. Dalam kurun waktu lebih dari satu dasawarasa sejak proklamasi, sebagian besar masyarakat Indonesia masih memberlakukan hukum agraria berdasarkan hukum barat (kolonial) dan sebagian kecil lainnya berdasarkan hukum adat. ${ }^{3}$ Hukum agraria yang berdasarkan hukum barat jelas memiliki tujuan dan sendi-sendi dari pemerintah jajahan. Hal ini dapat dipastikan bahwa pemberlakuan hukum agaria tersebut jelas tidak akan mampu mewujudkan cita-cita Negara sebagaimana yang tertuang dalam Undang-Undang Dasar Tahun 1945 Pasal 33 ayat (3), yaitu Bumi, air dan ruang angkasa serta kekayaan alam yang terkandung di dalamnya dikuasai oleh negara dan dipergunakan untuk sebesar-besarnya bagi kemakmuran rakyat. ${ }^{4}$

Salah satu tujuan dari pembentukan Undang-Undang Pokok Agraria adalah meletakkan dasar-dasar untuk memberikan kepastian dan perlindungan hukum mengenai hak atas tanah bagi rakyat Indonesia seluruhnya. Oleh karena itu, untuk dapat mewujudkan hal tersebut diselenggarakan pendaftaran tanah. Pendaftaran tanah dalam Undang-Undang Pokok Agraria diatur dalam Pasal 19 ayat (1) dan (2) : 5

(1) Untuk menjamin kepastian hukum oleh pemerintah diadakan pendaftaran tanah di seluruh wilayah Republik Indonesia menurut ketentuan-ketentuan yang diatur dalam Peraturan Pemerintah.

(2) Pendaftaran tanah dalam ayat 1 Pasal ini meliputi :

a. Pengukuran, perpetaan dan pembukuan tanah;

b. Pendaftaran hak-hak atas tanah dan peralihan hak-hak tersebut;

c. Pemberian surat-surat tanda bukti hak, yang berlaku sebagai alat bukti yang kuat.

Hasil dari proses pendaftaran tanah, kepada pemegang hak atas tanah yang didaftar diberikan surat tanda bukti hak yang disebut sertipikat. Sertipikat menurut Peraturan Pemerintah Nomor 24 Tahun 1997 tentang Pendaftaran Tanah adalah berupa satu lembar dokumen yang memuat data yuridis dan data fisik yang diperlukan dari suatu bidang tanah yang didaftar.

Terselenggaranya pendaftaran tanah memungkinkan bagi para pemegang hak atas tanah dapat dengan mudah membuktikan hak atas tanah yang dikuasainya. Bagi para pihak yang berkepentingan, seperti calon pembeli dan calon kreditur dapat dengan mudah untuk memperoleh keterangan yang diperlukan mengenai tanah yang menjadi objek perbuatan hukum yang akan dilakukan. Bagi pemerintah dapat membantu dalam melaksanakan kebijakan di bidang pertanahannya.

Pada awalnya pelaksanaan pendaftaran tanah diadakan menurut ketentuanketentuan yang diatur dalam Peraturan Pemerintah Nomor 10 Tahun 1961 Tentang Pendaftaran Tanah. Namun dalam perjalanan waktu keberadaan Peraturan Pendaftaran ini dianggap belum maksimal karena ada beberapa kendala diantaranya keterbatasan dana dan tenaga sehingga penguasaan tanah-tanah sebagian besar tidak didukung oleh alat pembuktian yang memadai. Selain itu Peraturan Pemerintah ini belum cukup memberikan kemungkinan untuk terlaksananya pendaftaran tanah dengan waktu yang singkat dan hasil yang memuaskan. Karena tidak ada batas waktu dalam mendaftarkan tanah yang diperoleh setelah peralihan hak, selain itu yang mendaftar tidak harus Pejabat Pembuat Akta tanah tetapi bisa juga pemilik baru dari hak atas tanah sehingga seringkali tanahnya tidak didaftarkan Untuk memperbaiki kelemahankelemahan ini dikeluarkanlah peraturan mengenai pendaftaran tanah yang baru untuk lebih menyempurnakan peraturan pendaftaran tanah sebelumnya, yaitu Peraturan Pemerintah Nomor 24 Tahun 1997 Tentang Pendaftaran Tanah. ${ }^{6}$

Peraturan Pemerintah Nomor 24 Tahun 1997 tetap mempertahankan tujuan dan sistem yang digunakan dalam Pasal 19 UUPA jo PP Nomor 10 Tahun 1961. Peraturan Pemerintah Nomor 24 Tahun 1997 merupakan penyempurnaan dari peraturan sebelumnya sehingga banyak terdapat tambahan, hal ini terlihat dari jumlah Pasal yang lebih banyak dan isi Peraturan Pemerintah tersebut yang lebih memberikan jaminan kepastian hukum dalam hal kepemilikan tanah. Salah satunya terdapat dalam Pasal 32 yang mengatur bahwa :

(1) Sertipikat merupakan surat tanda bukti hak yang berlaku sebagai alat pembuktian yang kuat mengenai data fisik dan data yuridis yang termuat di dalamnya, sepanjang data fisik dan data yuridis tersebut sesuai dengan data yang ada dalam surat ukur dan buku tanah hak yang bersangkutan.

(2) Dalam hal suatu bidang tanah sudah diterbitkan sertipikat secara sah atas nama orang atau badan hukum yang memperoleh tanah tersebut dengan itikad baik dan secara nyata menguasainya, maka pihak lain yang merasa mempunyai hak atas tanah itu tidak dapat lagi menuntut pelaksanaan hak tersebut apabila dalam jangka waktu (5) lima tahun sejak diterbitkannya sertipikat itu tidak mengajukan keberatan secara tertulis kepada pemegang sertipikat dan kepala Kantor Pertanahan yang bersangkutan ataupun tidak mengajukan gugatan ke Pengadilan mengenai penguasaan tanah atau penerbitan sertipikat tersebut.

Pada ayat (1) Pasal ini mengandung makna bahwa sertipikat merupakan alat pembuktian yang kuat dan selama tidak dapat dibuktikan sebaliknya maka data fisik dan data yuridis yang tercantum dalam sertipikat harus diterima sebagai data yang benar. ${ }^{7}$ Sedangkan ayat (2) Pasal ini lebih menegaskan lagi jaminan kepastian dan perlindungan hukum bagi pemegang sertipikat tanah, dimana mengandung beberapa syarat, diantaranya :

\footnotetext{
${ }^{2}$ Wayan Suandra, Hukum Pertanahan Indonesia, (Jakarta: Rienika Cipta, 1991), Hal.. 47.

${ }^{3}$ Soedikno Mertokusumo, Hukum dan Politik Agraria, (Jakarta: Karunika, 1988), Hal.. 445.

${ }^{4}$ Ibid., Hal.. 48.

${ }^{5}$ Boedi Harsono, Hukum Agraria Indonesia Himpunan Peraturan-Peraturan Hukum Tanah, (Jakarta: Djambatan, 2002 ), Hal.. 21.

${ }^{6}$ Suhariningsih, Tanah terlantar, (Jakarta: Prestasi Pustaka Publisher, 2009), Hal.. 277.

${ }^{7}$ A.P. Parlindungan, Kumpulan Tulisan Tentang Hukum Tanah, Cetakan I, (Bandung: Alumni, 1993), Hal.. 35.
} 
a. Sertipikat tanah diperoleh dengan itikad baik;

b. Pemegang hak atas tanah harus menguasai secara fisik tanahnya selama jangka waktu tertentu yaitu sejak lima tahun diterbitkannya sertipikat tanah tersebut;

c. Sejak lima tahun diterimanya sertipikat hak atas tanah bila tidak adanya keberatan dari pihak ketiga maka keberadaan sertipikat tanah tersebut tidak dapat diganggu gugat lagi;

Akibat dari semakin pentingnya keperluan akan tanah dan lajunya pertumbuhan penduduk akan menimbulkan berbagai masalah dibidang pertanahan, terutama dalam masalah kepemilikan dan penguasaan tanah berupa sengketa-sengketa tanah serta penggunaannya yang sering tumpang tindih, sehingga tidak sesuai lagi dengan peruntukannya. Sehubungan dengan itu perlu adanya dukungan berupa jaminan akan kepastian hukum dibidang pertanahan, sehingga hak-hak atas tanah yang dimiliki oleh masyarakat akan terlindungi.

Dalam perkembangan dewasa ini banyak terjadi sengketa berkaitan dengan tanah, salah satunya sengketa yang sering terjadi adalah sengketa tanah yang mengalami tumpang tindih atau disebut juga surat sertifikat ganda (overlapping). Surat sertifikat tumpang tindih merupakan surat-surat yang menyuratkan satu bidang tanah yang sama. Dengan demikian satu bidang tanah diuraikan dengan dua surat atau lebih yang berlainan datanya. Baik tumpang tindih seluruh bidang maupun tumpang tindih sebagian tanah tersebut. Surat sertifikat tumpang tindih merupakan salah satu permasalahan yang ditemukan dalam masyarakat, tingginya masalah pertanahan. ${ }^{8}$

Ketentuan dalam Pasal 32 ayat (2) tersebut sebenarnya bukan merupakan suatu ketentuan baru, karena konsep dari Pasal ini merupakan konsep yang dipakai dalam menyelesaikan sengketa tanah pada hukum dapat sebelum berlakunya Peraturan Pemerintah Nomor 24 Tahun 1997. Konsep yang digunakan dalam Pasal ini adalah "rechtsverwerking" yang sudah diterapakan sebelum Peraturan Pemerintah 24 Tahun 1997 berlaku bahkan jauh sebelum UUPA ada. Meskipun kepemilikan tanah telah diatur sedemikian rupa, namun masih saja terdapat permasalahan dalam hal kepemilikan sebidang tanah, misalnya saja terhadap sebidang tanah yang sudah dikuasai oleh subjek hukum selama bertahun-tahun dan telah dilengkapi dengan sertifikat. Terhadap tanah itu masih ada pihak luar yang menuntut hak atas tanah tersebut. Permasalahan ini sering terjadi di berbagai daerah di Indonesia. Sampai dengan saat ini Pasal 32 ayat (2) Peraturan Pemerintah Nomor 24 Tahun 1997 yang seharusnya dapat menjadi jalan keluar bagi permasalahan di atas masih mendapatkan banyak pro dan kontra. Mengingat keberadaan Kepastian Hukum terhadap Peraturan Pemerintah tersebut tidak sesuai dengan sistem publikasi negatif yang dianut oleh pendaftaran tanah di Indonesia, dimana sertipikat bukanlah merupakan alat bukti yang mutlak melainkan sertipikat merupakan alat bukti yang kuat.

Berdasarkan latar belakang yang telah dikemukakan di atas, maka masalah pokok yang diteliti adalah sebagai berikut Bagaimanakah Bagaimanakah kepastian hukum sertifikat hak milik atas tanah dalam hukum pertanahan Indonesia? Dan idealnya kepemilikan tanah agar memiliki kepastian hukum yang sesuai Undang-Undang Nomor 5 Tahun 1960 tentang Peraturan Dasar Pokok-Pokok Agraria?

\section{METODE PENELITIAN}

Dilihat dari jenisnya maka penelitian ini dapat digolongkan kepada penelitian normatif yang membahas tentang Kepastian Hukum Sertifikat Hak Milik Atas Tanah Dalam Hukum Pertanahan Indonesia. Pendekatan penelitian yang digunakan dalam menjelaskan dan menjawab permasalahan penelitian adalah pendekatan undang-undang/yuridis yakni pendekatan yang digunakan untuk mengkaji dan menganalisis undang-undang/peraturan yang terkait dengan permasalahan penelitian. Pendekatan penelitian yang digunakan penulis dalam penelitian ini adalah menggunakan pendekatan Undang-Undang (Statue Approach), pendekatan Historis (Story Approach), Pendekatan Konseptual (Conceptual Approach), dan Pendekatan perbandingan hukum (Comparison approach). Peneliti perlu mencari ratio legis dan dasar ontologis lahirnya Undang-Undang Nomor 5 Tahun 1990 Tentang Undang-Undang Pokok Agraria dan Peraturan Pemerintah Nomor 24 Tahun 1997 Tentang Pendaftaran Tanah.?

\section{ANALISIS DAN PEMBAHASAN}

\section{Kepastian Hukum Sertifikat Hak Milik Atas Tanah Dalam Hukum Pertanahan Indonesia}

Hak milik adalah hak yang sangat asasi dan merupakan hak dasar yang dijamin konstitusi. Kepastian hukum tanah yang bagi yang belum sertifikat terhadap hak tanah bersertifikat, apabila dihubungkan dengan Pasal 28D ayat (1) UUD1945, yang menyatakan bahwa: "Setiap orang berhak atas pengakuan, jaminan, perlindungan, dan kepastian hukum yang adil serta perlakuan yang sama di hadapan hukum". Sedangkan berdasarkan Pasal 28H ayat (4) UUD 1945 mengatur bahwa "setiap orang berhak mempunyai hak milik pribadi dan hak tersebut tidak boleh diambil alih secara sewenang-wenang oleh siapa pun". Sementara itu, UUPA sebagai peraturan dasar hukum tanah nasional mengatur bahwa "hak milik atas tanah adalah hak turuntemurun, terkuat dan terpenuh yang dapat dipunyai orang atas tanah, dengan mengingat ketentuan bahwa semua hak atas tanah mempunyai fungsi sosial" (Pasal 20 UUPA). Dalam konsep hukum, hubungan antara orang dengan benda merupakan hubungan yang disebut "Hak". Makna dari sebutan itu adalah hak kepemilikan atas suatu benda yang disebut hak milik atas benda itu atau

\footnotetext{
${ }^{8}$ Ibid., Hal.. 40.

${ }_{9}^{9}$ Peter Mahmud Marzuku, Penelitain Hukum, Cetakan Ke- 11, (Jakarta: Kencana, 2011), Hal.. 93.
} 
yang dikenal dengan istilah "property right". Kata milik itu sendiri dalam makna hukum lebih menekankan pada hak dari pada kepada bendanya. Aspek hukum itu penting untuk mencapai keamanan hukum yang diperlukan untuk kepemilikan tanah. Semua hak kebendaan atas tanah adalah barang-barang yang terdaftar. Sebuah hak kebendaan adalah $:^{10}$

1. Sebuah hak yang mengikuti objek (droit de suite);

2. Sebuah hak yang memiliki prioritas terhadap hak-hak kebendaan (in rem: perihal sesuatu) yang lebih muda (droit de priorite, prior tempore potior iure); dan

3. Sebuah hak yang memiliki prioritas terhadap hak-hak perorangan (in personam: perihal seseorang) secara umum (droit de preference). ${ }^{11}$

Negara memiliki kekuasaan untuk menguasai tanah yang berada dalam wilayah kekuasaannya. Hal ini dipertegas bahwa negara tidak hanya menguasai tanah tetapi juga memiliki wewenang untuk mengatur peruntukkan tanah-tanah itu. UUPA telah mengatur dengan jelas hak atas tanah seperti hak milik, hak guna usaha, hak guna bangunan, hak pakai, hak sewa untuk bangunan, dan hak tanah yang bersifat sementara seperti hak gadai, hak usaha bagi hasil, hak menumpang dan sebagainya. Pengertian bumi meliputi permukaan bumi (yang disebut tanah), tubuh bumi di bawahnya serta yang berada di bawah air. Dengan demikian pengertian tanah meliputi permukaan bumi yang ada di daratan dan permukaan bumi yang berada di bawah air, termasuk air laut. ${ }^{12}$ Hal ini diatur dalam Pasal 2 ayat (2) UUPA yang memberikan wewenang kepada negara untuk:

1. Mengatur dan menyelenggarakan peruntukkan, penggunaan, persediaan dan pemeliharaan bumi, air dan ruang angkasa;

2. Menentukan dan mengatur hubungan-hubungan hukum antara orang dengan bumi, air dan ruang angkasa; dan

3. Menentukan dan mengatur hubungan-hubungan hukum yang mengenai bumi, air dan ruang angkasa.

Sedangkan kepemilikan surat hak atas tanah dalam rangka mewujudkan kepastian hukum diatur dalam Pasal 19 UUPA, yang menyatakan:

1. Untuk menjamin kepastian hukum oleh Pemerintah diadakan pendaftaran tanah di seluruh wilayah Republik Indonesia menurut ketentuan-ketentuan yang diatur dengan Peraturan Pemerintah".

2. Pendaftaran tersebut dalam ayat (1) Pasal ini meliputi:

a. Pengukuran perpetaan dan pembukuan tanah;

b. Pendaftaran hak-hak atas tanah dan peralihan hak-hak tersebut;

c. Pemberian surat-surat tanda bukti hak, yang berlaku sebagai alat pembuktian yang kuat.

3. Pendaftaran tanah diselenggarakan dengan mengingat keadaan negara dan masyarakat, keperluan lalu lintas sosial ekonomi serta kemungkinan penyelenggaraannya, menurut pertimbangan Menteri Agraria.

4. Dalam Peraturan Pemerintah diatur biaya-biaya yang bersangkutan dengan pendaftaran termaksud dalam ayat (1) di atas, dengan ketentuan bahwa rakyat yang tidak mampu dibebaskan dari pembayaran biaya-biaya tersebut.

Berdasarkan atas Pasal 19 UUPA tersebut di atas, maka ditegaskan dalam Pasal 3 PP Nomor 24 Tahun 1997 telah diatur lebih lanjut sebagai penegasan tentang hak tersebut sebagai berikut:

1. Untuk memberikan kepastian hukum dan perlindungan hukum kepada pemegang hak atas suatu bidang tanah, satuan rumah susun dan hak-hak lain yang terdaftar agar dengan mudah dapat membuktikan dirinya sebagai pemegang hak yang bersangkutan.

2. Untuk menyediakan informasi kepada pihak-pihak yang berkepentingan termasuk Pemerintah agar dengan mudah dapat memperoleh data yang diperlukan dalam mengadakan perbuatan hukum mengenai bidangbidang tanah dan satuan-satuan rumah susun yang sudah terdaftar.

3. Untuk terselenggaranya tertib administrasi pertanahan.

Sehingga jelaslah PP Nomor 24 Tahun 1997 ini telah memperkaya ketentuan Pasal 19 UUPA, yaitu:

1. Bahwa dengan diterbitkannya sertifikat hak atas tanah maka kepada pemiliknya diberikan kepastian hukum dan perlindungan hukum.

2. Di zaman informasi ini maka Kantor Pertanahan sebagai kantor digaris depan haruslah terpelihara dengan baik setiap informasi yang diperlukan untuk sesuatu bidang tanah, baik untuk pemerintah sendiri sehingga dapat merencanakan pembangunan negara dan juga bagi masyarakat sendiri informasi itu penting untuk dapat memutuskan suatu yang diperlukan dimana terlihat tanah, yaitu data fisik dan yuridisnya termasuk satuan rumah susun. Infomasi tersebut bersifat terbuka untuk umum artinya dapat diberikan informasi apa saja yang diperlukan atas sebidang tanah/bangunan yang ada.

3. Sehingga untuk itu perlulah tertib administrasi pertanahan dijadikan suatu hal yang wajar. ${ }^{13}$

\footnotetext{
${ }^{10}$ Muchtar Wahid, Memaknai Kepastian Hukum Hak Milik Atas Tanah: Suatu Analisis dengan Pendekatan Terpadu Secara Normatif dan Sosiologi, (Jakarta: Republika, 2008), Hal. 43.

${ }^{11}$ Arie Sukanti Hutagalung, dkk, Hukum Pertanahan di Belanda dan Indonesia, (Denpasar: Pustaka Larasan, 2012 ), Hal.. 6.

12 Boedi Harsono, Hukum Agraria Indonesia, Sejarah Pembentukan UUPA, Isi dan Pelaksanaannya. Jilid I: Hukum Tanah Nasional, (Jakarta: Djambatan, 2003), Hal.. 6

${ }^{13}$ Parlindungan, AP, Pendaftaran Tanah di Indonesia (Berdasarkan PP No. 24 Tahun 1997), (Bandung: Mandar Maju, 2009$)$, Hal.. 2.
} 
UUPA menegaskan bahwa pemberian hak atas tanah atas suatu bidang tanah tertentu diberikan untuk digunakan atau dimanfaatkan. Diberikannya dan dimilikinya tanah dengan hak-hak penggunaannya tidak akan bermakna, jika penggunaannya terbatas pada tanah sebagai permukaan bumi. Pemanfaatan tanah selalu berbarengan dengan pemanfaatan apa yang ada di permukaan bumi dan di atasnya. Oleh karenanya hak-hak atas tanah bukan hanya memberikan wewenang untuk mempergunakan sebagian tertentu permukaan bumi yang disebut tanah, tetapi juga tubuh bumi yang ada di bawahnya dan air serta ruang angkasa yang ada di atasnya. Dengan demikian makna yang dimiliki dengan hak atas tanah adalah tanahnya, dalam arti sebagian tertentu dari permukaan bumi. Namun, wewenang penggunaan yang bersumber pada hak atas tanah tersebut diperluas hingga meliputi sebagian tubuh bumi yang ada di bawah tanah dan air serta ruang angkasa yang ada di atasnya. ${ }^{14}$ Dalam pengertian konteks agraria, tanah berarti permukaan bumi paling luar berdimensi dua dengan ukuran panjang dan lebar. Hukum tanah di sini bukan mengatur tanah dalam segala aspeknya, melainkan hanya mengatur salah satu aspeknya saja yaitu aspek yuridisnya yang disebut dengan hak-hak penguasaan atas tanah. Dalam hukum, tanah merupakan sesuatu yang nyata yaitu berupa permukaan fisik bumi serta apa yang ada diatasnya buatan manusia. Walaupun demikian perhatian utamanya adalah bukan tanahnya itu, melainkan kepada aspek kepemilikan dan penguasaan tanah serta perkembangannya. Objek perhatiannya adalah hak-hak dan kewajiban-kewajiban berkenaan dengan tanah yang dimiliki dan dikuasai dalam berbagai bentuk hak penguasaan atas tanah.

Untuk mendapatkan jaminan kepastian hukum atas bidang tanah, memerlukan perangkat hukum yang tertulis, lengkap, jelas dan dilaksanakan secara konsisten sesuai dengan jiwa dan isi ketentuan-ketentuan yang berlaku. Hal tersebut tercapai melalui pendaftaran tanah. Sebagai bagian dari proses pendaftaran tanah, sertifikat sebagai alat pembuktian hak atas tanah terkuat pun diterbitkan. Dokumen-dokumen pertanahan sebagai hasil proses pendaftaran tanah adalah dokumen tertulis yang memuat data fisik dan data yuridis tanah bersangkutan. Dokumen-dokumen pertanahan tersebut dapat dipakai sebagai jaminan dan menjadi pegangan bagi pihak-pihak lain yang memiliki kepentingan atas tanah tersebut. ${ }^{15}$ Pembaruan bidang hukum agraria khususnya pendaftaran tanah dilaksanakan dengan perubahan-perubahan peraturan pendaftaran tanah, hal ini dimaksudkan dalam rangka lebih untuk menjamin kepastian hukum. Pendaftaran tanah meliputi:

1. Pengukuran, pemetaan dan pembukuan tanah;

2. Pendaftaran hak-hak atas tanah dan peralihan hak-hak tersebut; dan

3. Pemberian surat tanda bukti hak yang berlaku sebagai alat pembuktian yang kuat.

Penyelenggaraan pendaftaran tanah dikenal adanya dua sistem pendaftaran tanah yaitu:

1. Sistem publikasi positif yaitu sistem dimana pendaftaran tanah seseorang dalam daftar-daftar umum karena memperoleh hak dengan itikad baik tidak dapat diganggu gugat. Sehingga pemegang hak dikemudian hari akan kehilangan haknya dan hanya mendapatkan ganti rugi; dan

2. Sistem publikasi negatif yaitu sistem dimana bahwa terdaftarnya seseorang dalam daftar umum sebagai pemegang hak, tidak mengakibatkan bahwa yang sebenarnya berhak akan kehilangan hak nya, dengan kata lain pemegang hak terdahulu bisa kehilangan hak nya apabila terbukti dengan putusan pengadilan bahwa pemegang hak dikemudian hari dibenarkan oleh putusan pengadilan.

Pendaftaran tanah juga mewajibkan pemegang hak atas tanah untuk melakukan pendaftaran haknya. Secara etimologi sertifikat berasal dari bahasa Belanda "certificaat" yang artinya surat bukti atau surat keterangan yang membuktikan tentang sesuatu. Maka sertifikat tanah adalah surat keterangan yang membuktikan hak seseorang atas sebidang tanah, atau dengan kata lain keadaan tersebut menyatakan bahwa ada seseorang yang memiliki bidang-bidang tanah tertentu dan pemilikan itu mempunyai bukti yang kuat berupa surat yang dibuat instansi yang berwenang. Dilihat dari aspek jaminan yang diberikan dengan pemberian surat-surat tanda bukti hak atas tanah (sertifikat hak atas tanah), sebagai alat pembuktian, maka rechts kadaster (pendaftaran tanah) mengenal dua macam sistem, yaitu sistem negatif dan sistem positif.

Selama ini, masalah pertanahan khususnya yang terkait dengan kegiatan pengukuran dan pemetaan tanah sangat mudah terjadi. Salah satu penyebab permasalahan tersebut adalah banyaknya peta yang digunakan oleh suatu kantor pertanahan untuk memetakan bidang-bidang tanah yang terdaftar sehingga kepastian letak suatu persil atau bidang tanah menjadi tidak terjamin. Permasalahan tersebut dapat diatasi apabila ada kepastian data mengenai bidang-bidang tanah yang terdaftar pada kantor pertanahan. Untuk menciptakan kepastian mengenai bidang-bidang tanah yang terdaftar tersebut harus dibangun satu sistem peta pendaftaran secara tunggal. Dengan peta tunggal, setiap bidang tanah yang terdaftar hanya akan dipetakan pada satu peta untuk satu wilayah dalam lokasi yang bersangkutan. Untuk menjamin kepastian hak dan kepastian hukum apabila tanah sudah dikuasai oleh masyarakat yang waktunya sudah cukup lama dan tidak ada sanggahan pihak lain, maka tanah tersebut sudah menjadi tanah negara bebas. Dalam hal ini diperlukan pembuktian tertulis yang diketahui Lurah atau Kepala Desa dan Camat setempat untuk memenuhi unsur kepastian hukum. Oleh sebab itu, diperlukan pengumuman di mass media cetak bila diperlukan yang dapat berupa media elektronik yang dikenal dalam hukum perdata sebagai asas publisitas.

Tugas untuk melakukan pendaftaran tanah di seluruh Indonesia dibebankan kepada pemerintah yang oleh Pasal 19 ayat (1) UUPA ditentukan bertujuan untuk menjamin kepastian hukum. Menurut penjelasan dari UUPA, pelaksanaan kegiatan pendaftaran tanah merupakan kewajiban dari pemerintah bertujuan menjamin kepastian hukum yang bersifat rechts cadaster. Rechts cadaster artinya untuk kepentingan pendaftaran tanah saja dan hanya mempermasalahkan haknya apa dan siapa

${ }^{14}$ Boedi Harsono, Hukum Agraria Indonesia, Sejarah ...Op. Cit., , Hal.. 18.

${ }^{15}$ Florianus SP Sangsung, Tata Cara Mengurus Sertifikat Tanah, (Jakarta: Visimedia, 2007), Hal.. 1-2. 
pemiliknya. Kepastian hukum yaitu sesuatu yang bersifat tetap dijamin melalui undang-undang atau ketetapan lainnya oleh negara yang dapat melindungi segala sesuatu yang dimiliki oleh seseorang. Dengan diterbitkannya sertifikat sebagai hasil akhir kegiatan pendaftaran tanah untuk pertama kalinya, maka terwujud jaminan kepastian hukum dan perlindungan hukum bagi pemegang haknya. Dalam rangka pembuktian hak atas tanah, maksud diterbitkannya hak atas tanah adalah agar dengan mudah dapat membuktikan nama yang tercantum dalam sertifikat sebagai pemegang hak yang bersangkutan.

Kepastian hukum harus diterapkan untuk mencapai keadilan dan kebijakan pertanahan dapat dilaksanakan secara konsisten. Dalam rangka untuk memberikan kepastian dan perlindungan hukum, maka kepada pemegang hak atas tanah yang bersangkutan diberikan sertifikat hak atas tanah. Sertifikat diterbitkan untuk kepentingan pembuktian pemegang hak yang bersangkutan sesuai dengan data fisik dan data yuridis yang telah didaftarkan dalam buku tanah. Dengan data fisik dan data yuridis yang tercantum didalam sertifikat harus sesuai dengan data yang tercantum didalam buku tanah dan surat ukur yang bersangkutan. Pendaftaran atas bidang tanah dilakukan agar mendapatkan kepastian hukum bagi pemegang hak atas tanah maupun pihak lain yang berkepentingan dengan tanah. Penggunaan tanah harus disesuaikan dengan keadaannya dan sifat daripada haknya, hingga bermanfaat baik bagi kesejahteraan dan kebahagiaan yang mempunyainya maupun bermanfaat pula bagi masyarakat dan negara. Ketentuan tersebut tidak berarti, bahwa kepentingan perseorangan akan terdesak sama sekali oleh kepentingan umum. UUPA juga memperhatikan kepentingan perseorangan haruslah saling mengimbangi, hingga pada akhirnya akan tercapai tujuan pokok yaitu kemakmuran, keadilan dan kebahagiaan bagi rakyat seluruhnya. Dalam rangka tercapainya keadilan, kemakmuran, perlindungan, dan kepastian hukum dengan adanya pendaftaran tanah dan penerbitan sertifikat, maka akan tercapailah kepastian hukum akan hak-hak atas tanah, karena data yuridis dan data fisik yang tercantum dalam sertifikat tanah tersebut diterima sebagai data yang benar. Sertifikat hak atas tanah adalah tanda bukti atas tanah yang telah terdaftar dan didaftar oleh badan resmi yang sah dilakukan oleh negara atas dasar undang-undang. Sehingga dengan pengeluaran sertifikat ini, menandakan telah ada pendaftaran tanah yang dilakukan, dan pendaftaran ini akan menciptakan keuntungan akibat pelaksanaan administrasi pertanahan yang sah.

Kepastian hukum mengenai hak atas tanah untuk memberikan kepastian mengenai objek hak atas tanah, kepastian mengenai subjek hak atas tanah dan kepastian mengenai status hak atas tanah. Konsepsi hukum sertifikat hak atas tanah merupakan tanda bukti yang diterbitkan oleh lembaga hukum yang berwenang, yang berisi data yuridis dan data fisik yang digunakan sebagai alat bukti kepemilikan hak atas tanah dengan tujuan guna memberikan jaminan kepastian hukum dan kepastian hak atas sebidang tanah yang dimiliki atau dipunyai oleh seseorang maupun badan hukum. Dengan adanya sertifikat hak maka diharapkan secara yuridis dapat memberikan jaminan kepastian hukum dan hak oleh negara bagi pemegang hak atas tanahnya. Jaminan negara ini diberikan kepada pemilik atau pemegang sertifikat dapat diberikan karena tanahnya sudah terdaftar dalam sistem administrasi pertanahan negara.

Pilihan kebijakan hukum pertanahan tentang stelsel publisitas negatif (berunsur positif) mengacu pada sistem pendaftaran tanah di dunia dikenal dua model atau jenis pendaftaran tanah yang disebut dengan pertama, model sistem pendaftaran akta (registration of deeds) atau disebut pula pendaftaran tanah dengan stelsel publisitas negatif dan kedua, model sistem pendaftaran tanah (registration of title) atau disebut dengan stelsel publisitas positif (sistem torrens). ${ }^{16}$ Pokok-pokok tujuan diberlakukannya Undang-Undang Pokok Agraria, adalah untuk meletakkan dasar-dasar bagi penyusunan hukum agraria nasional yang akan merupakan alat untuk membawa kemakmuran, kebahagiaan dan keadilan bagi negara dan rakyat, terutama rakyat tani, dalam rangka mewujudkan masyarakat yang adil dan makmur, meletakkan dasar-dasar untuk kesatuan dan kesederhanaan dalam hukum pertanahan, serta meletakkan dasar-dasar untuk memberi kepastian hukum mengenai hak-hak atas tanah bagi seluruh rakyat. Kepastian hukum bagi pemilik hak atas tanah, oleh Undang-Undang Pokok Agraria sendiri disebutkan, hanya dapat diperoleh melalui prosedur pendaftaran tanah. Dalam mewujudkan tanah untuk keadilan dan kesejahteraan, arah dan kebijakan pertanahan didasarkan pada 4 (empat) prinsip, yaitu:

1. Pertanahan harus berkontribusi secara nyata untuk meningkatkan kesejahteraan rakyat dan melahirkan sumber-sumber baru kemakmuran;

2. Pertanahan harus berkontribusi secara nyata untuk meningkatkan tatanan kehidupan bersama yang lebih berkeadilan dalam kaitannya dengan pemanfaatan penggunaan, penguasaan, dan pemilikan tanah;

3. Pertanahan harus berkontribusi nyata dalam menjamin berkelanjutan sistem kemasyarakatan kebangsaan dan kenegaraan Indonesia dengan memberikan akses seluas-seluasnya pada generasi yang akan datang pada sumbersumber ekonomi; dan

4. Pertanahan harus berkontribusi secara nyata dalam menciptakan tatanan kehidupan bersama secara harmonis dengan mengatasi berbagai sengketa dan konflik pertanahan dan menata sistem pengelolaan yang tidak lagi melahirkan sengketa dan konflik dikemudian hari. ${ }^{17}$

Untuk mendapatkan jaminan kepastian hukum atas bidang tanah, memerlukan perangkat hukum yang tertulis, lengkap, jelas dan dilaksanakan secara konsisten sesuai dengan jiwa dan isi ketentuan-ketentuan yang berlaku. Hal tersebut tercapai melalui pendaftaran tanah. Sebagai bagian dari proses pendaftaran tanah, sertifikat sebagai alat pembuktian hak atas tanah terkuat pun diterbitkan. Dokumen-dokumen pertanahan sebagai hasil proses pendaftaran tanah adalah dokumen tertulis yang memuat data fisik dan data yuridis tanah bersangkutan. Dokumen-dokumen pertanahan tersebut dapat dipakai sebagai jaminan

${ }^{16}$ Ibid., Hal.. 22.

${ }^{17}$ Sudantoko, Djoko dan Hamdani, Muliawan, Dasar-Dasar Pengantar Ekonomi Pembangunan, (Jakarta: PT PP Mardi Mulya, 2009$)$, Hal.. 85. 
dan menjadi pegangan bagi pihak-pihak lain yang memiliki kepentingan atas tanah tersebut. ${ }^{18}$ Pembaruan bidang hukum agraria khususnya pendaftaran tanah dilaksanakan dengan perubahan-perubahan peraturan pendaftaran tanah, hal ini dimaksudkan dalam rangka lebih untuk menjamin kepastian hukum. Pendaftaran tanah meliputi:

1. Pengukuran, pemetaan dan pembukuan tanah;

2. Pendaftaran hak-hak atas tanah dan peralihan hak-hak tersebut; dan

3. Pemberian surat tanda bukti hak yang berlaku sebagai alat pembuktian yang kuat.

Penyelenggaraan pendaftaran tanah dikenal adanya dua sistem pendaftaran tanah yaitu: ${ }^{19}$

1. Sistem publikasi positif yaitu sistem dimana pendaftaran tanah seseorang dalam daftar-daftar umum karena memperoleh hak dengan itikad baik tidak dapat diganggu gugat. Sehingga pemegang hak dikemudian hari akan kehilangan haknya dan hanya mendapatkan ganti rugi; dan

2. Sistem publikasi negatif yaitu sistem dimana bahwa terdaftarnya seseorang dalam daftar umum sebagai pemegang hak, tidak mengakibatkan bahwa yang sebenarnya berhak akan kehilangan hak nya, dengan kata lain pemegang hak terdahulu bisa kehilangan hak nya apabila terbukti dengan putusan pengadilan bahwa pemegang hak dikemudian hari dibenarkan oleh putusan pengadilan.

Pendaftaran tanah juga mewajibkan pemegang hak atas tanah untuk melakukan pendaftaran haknya. Secara etimologi sertifikat berasal dari bahasa Belanda "certificaat" yang artinya surat bukti atau surat keterangan yang membuktikan tentang sesuatu. Maka sertifikat tanah adalah surat keterangan yang membuktikan hak seseorang atas sebidang tanah, atau dengan kata lain keadaan tersebut menyatakan bahwa ada seseorang yang memiliki bidang-bidang tanah tertentu dan pemilikan itu mempunyai bukti yang kuat berupa surat yang dibuat instansi yang berwenang. Dilihat dari aspek jaminan yang diberikan dengan pemberian surat-surat tanda bukti hak atas tanah (sertifikat hak atas tanah), sebagai alat pembuktian, maka rechts kadaster (pendaftaran tanah) mengenal dua macam sistem, yaitu sistem negatif dan sistem positif. ${ }^{20}$

Dalam sistem negatif bahwa sertifikat tersebut hanya dapat dipandang sebagai suatu bukti permulaan hak atas tanahnya, atau sertifikat sebagai salah satu alat pembuktian yang kuat, sehingga setiap orang dapat mempersoalkannya kembali. Pemilik tanah diberikan jaminan lebih kuat, apabila dibandingkan perlindungan yang diberikan kepada pihak ketiga. Dengan demikian, maka pemilik tanah dapat menggugat haknya atas sebidang tanah dari mereka yang terdaftar pada kadaster. Dengan mengandung unsur positif, untuk memberikan kepastian hukum kepada pihak yang dengan iktikad baik menguasai sebidang tanah yang didaftar sebagai pemegang hak dalam buku tanah dan dengan diterbitkannya sertifikat sebagai salah satu alat bukti yang kuat. Kepada yang memperoleh hak atas tanah akan diberikan jaminan lebih kuat, pihak ketiga harus percaya dan tidak perlu khawatir bila pada suatu ketika mereka atau orang-orang yang tercatat dalam daftar umum akan kehilangan haknya atau dirugikan.

Selama ini, masalah pertanahan khususnya yang terkait dengan kegiatan pengukuran dan pemetaan tanah sangat mudah terjadi. Salah satu penyebab permasalahan tersebut adalah banyaknya peta yang digunakan oleh suatu kantor pertanahan untuk memetakan bidang-bidang tanah yang terdaftar sehingga kepastian letak suatu persil atau bidang tanah menjadi tidak terjamin. Permasalahan tersebut dapat diatasi apabila ada kepastian data mengenai bidang-bidang tanah yang terdaftar pada kantor pertanahan. Untuk menciptakan kepastian mengenai bidang-bidang tanah yang terdaftar tersebut harus dibangun satu sistem peta pendaftaran secara tunggal. Dengan peta tunggal, setiap bidang tanah yang terdaftar hanya akan dipetakan pada satu peta untuk satu wilayah dalam lokasi yang bersangkutan. Untuk menjamin kepastian hak dan kepastian hukum apabila tanah sudah dikuasai oleh masyarakat yang waktunya sudah cukup lama dan tidak ada sanggahan pihak lain, maka tanah tersebut sudah menjadi tanah negara bebas. Dalam hal ini diperlukan pembuktian tertulis yang diketahui Lurah atau Kepala Desa dan Camat setempat untuk memenuhi unsur kepastian hukum. Oleh sebab itu, diperlukan pengumuman di mass media cetak bila diperlukan yang dapat berupa media elektronik yang dikenal dalam hukum perdata sebagai asas publisitas.

Tugas untuk melakukan pendaftaran tanah di seluruh Indonesia dibebankan kepada pemerintah yang oleh Pasal 19 ayat (1) Undang-Undang Pokok Agraria ditentukan bertujuan untuk menjamin kepastian hukum. Menurut penjelasan dari UndangUndang Pokok Agraria, pelaksanaan kegiatan pendaftaran tanah merupakan kewajiban dari pemerintah bertujuan menjamin kepastian hukum yang bersifat rechts cadaster. Rechts cadaster artinya untuk kepentingan pendaftaran tanah saja dan hanya mempermasalahkan haknya apa dan siapa pemiliknya. ${ }^{21}$ Kepastian hukum yaitu sesuatu yang bersifat tetap dijamin melalui undang-undang atau ketetapan lainnya oleh negara yang dapat melindungi segala sesuatu yang dimiliki oleh seseorang. Dengan diterbitkannya sertifikat sebagai hasil akhir kegiatan pendaftaran tanah untuk pertama kalinya, maka terwujud jaminan kepastian hukum dan perlindungan hukum bagi pemegang haknya. Dalam rangka pembuktian hak atas tanah, maksud diterbitkannya hak atas tanah adalah agar dengan mudah dapat membuktikan nama yang tercantum dalam sertifikat sebagai pemegang hak yang bersangkutan.

Seiring dengan perkembangan ekonomi dan kebutuhan masyarakat yang berkaitan dengan tanah, maka pendaftaran tanah sangatlah penting guna menjamin kepastian dan perlindungan hukum bagi pemilik tanah, yang selanjutnya dikonkretkan dengan penerbitan sertifikat hak atas tanah tersebut sebagai alat pembuktian yang kuat. Demikian pentingnya peranan sertifikat, sehingga kekuatan pembuktiannya tidak hanya berlaku eksternal/terhadap pihak luas, tetapi juga mempunyai daya kekuatan

\footnotetext{
${ }^{18}$ Florianus SP Sangsung, Tata Cara Mengurus ... Op.Cit., Hal.. 1-2.

${ }^{19} \mathrm{Ibid}$, Hal.. 4.

${ }^{20}$ Ibid, Hal.11.

${ }^{21}$ Mochtar Kusumaatmadja, Fungsi Hukum dan Perkembangan Hukum Dalam Pembangunan Nasional, (Bandung: Bina Cipta, 1976), Hal.. 10.
} 
internal, yakni memberikan rasa aman bagi para pemegang/pemiliknya serta ahli warisnya agar ahli warisnya di kemudian hari tidak mengalami kesulitan, dalam arti tidak perlu bersusah payah untuk mengurusnya; paling-paling harus menjaga keamanannya serta menghindari kerusakannya. Dalam rangka untuk memberikan kepastian dan perlindungan hukum, maka kepada pemegang hak atas tanah yang bersangkutan diberikan sertifikat hak atas tanah, sedangkan untuk melaksanakan fungsi informasi, data yang berkaitan dengan aspek fisik dan yuridis dari bidang-bidang tanah yang sudah terdaftar, dinyatakan terbukti untuk umum (asas publisitas), sementara dalam hal mencapai tujuan tertib administrasi pertanahan, maka setiap bidang tanah atau satuan rumah susun, termasuk peralihan, pembebanan dan hapusnya hak atas tanah dan hak milik satuan rumah susun, wajib didaftar.

Kepastian hukum mengenai hak atas tanah untuk memberikan kepastian mengenai objek hak atas tanah, kepastian mengenai subjek hak atas tanah dan kepastian mengenai status hak atas tanah. ${ }^{22}$ Konsepsi hukum sertifikat hak atas tanah merupakan tanda bukti yang diterbitkan oleh lembaga hukum yang berwenang, yang berisi data yuridis dan data fisik yang digunakan sebagai alat bukti kepemilikan hak atas tanah dengan tujuan guna memberikan jaminan kepastian hukum dan kepastian hak atas sebidang tanah yang dimiliki atau dipunyai oleh seseorang maupun badan hukum. Dengan adanya sertifikat hak maka diharapkan secara yuridis dapat memberikan jaminan kepastian hukum dan hak oleh negara bagi pemegang hak atas tanahnya. Jaminan negara ini diberikan kepada pemilik atau pemegang sertifikat dapat diberikan karena tanahnya sudah terdaftar dalam sistem administrasi pertanahan negara.

\section{Idealnya kepemilikan tanah agar memiliki kepastian hukum yang sesuai Undang-Undang Nomor 5 Tahun 1960 tentang Peraturan Dasar Pokok-Pokok Agraria}

Tanah dan pertanahan merupakan unsur vital dalam kehidupanberbangsa dan bernegara, karena menjadi sumbersumber keadilan dankemakmuran masyarakat. Hubungan bangsa Indonesia dengan tanahmencirikan hubungan yang bersifat abadi. ${ }^{23}$ Pemberian jaminan hukum dibidang pertanahan, pertama-tama memerlukan tersediamya perangkat hukum yang tertulis, lengkap dan jelas. Tanah dan bangunan merupakan benda-benda yang memegang peranan penting dalam kehidupan manusia. Tanah dan bangunan merupakan salah satu kebutuhan pokok manusia (kebutuhan papan) yang mempengaruhi eksistensi tiaptiap individu karena setiap manusia membutuhkan tempat untuk menetap.Hak-hak atas tanah mempunyai peranan sangat penting dalam kehidupan manusia ini, makin maju masyarakat, makin padat penduduknya, akan menambah lagi pentingnya kedudukan hak-hak atas tanah itu. ${ }^{24}$

Kebutuhan akan tanah dewasa ini semakin meningkat sejalan dengan bertambahnya jumlah penduduk, jumlah badan usaha, dan meningkatnya kebutuhan lain yang berkaitan dengan tanah. Tanah tidak saja sebagai tempat bermukim, tempat untuk bertani, tetapi juga dapat dipakai sebagai jaminan mendapatkan pinjaman bank, untuk keperluan jual beli dan sewa menyewa. Begitu pentingnya kegunaan tanah bagi orang atau badan hukum menuntut adanya jaminan kepastian hukum atas tanah tersebut. Untuk mendapatkan jaminan kepastian hukum atas bidang tanah, memerlukan perangkat hukum yang tertulis, lengkap, jelas dan dilaksanakan secara konsisten sesuai dengan jiwa dan isi ketentuan-ketentuan yang berlaku. ${ }^{25}$

Dalam era globalisasi dan liberalisasi perekonomian dewasa ini, maka peranan tanah bagi berbagai keperluan akan meningkat, baik sebagai tempat bermukim maupun untuk kegiatan bisnis. Sehubungan dengan hal tersebut akan meningkat pula kebutuhan akan dukungan berupa kepastian hukum di bidang pertanahan. Pemberian kepastian hukum di bidang pertanahan ini, memerlukan tersedianya perangkat hukum yang tertulis, lengkap dan jelas yang dilaksanakan secara konsisten sesuai dengan jiwa dan isi ketentuan-ketentuannya. Selain itu, dalam rangka menghadapi berbagai kasus nyata diperlukan pula terselenggaranya kegiatan pendaftaran tanah yang memungkinkan bagi para pemegang hak atas tanah untuk dengan mudah membuktikan haknya atas tanah yang dikuasainya, dan bagi para pihak yang berkepentingan, seperti calon pembeli dan calon kreditur, untuk memperoleh keterangan yang diperlukan mengenai tanah yang menjadi obyek perbuatan hukum yang akan dilakukan, serta bagi pemerintah untuk melaksanakan kebijakan pertanahan. ${ }^{26}$

Alas hak diartikan sebagai bukti penguasaan hak atas tanah secara yuridis dapat berupa alat-alat bukti yang menetapkan atau menerangkan adanya hubungan hukum antara tanah dengan yang mempunyai tanah, dapat pula berupa riwayat pemilikan tanah yang pernah diterbitkan oleh pejabat pemerintah sebelumnya maupun bukti pengakuan dari pejabat yang berwenang. Alas hak secara yuridis ini biasanya dituangkan dalam bentuk tertulis dengan suatu surat keputusan, surat keterangan, surat pernyataan, akta otentik maupun surt dibawah tangan lain-lain. ${ }^{27}$

Upaya pemerintah untuk memberikan suatu bentuk jaminan akan adanya kepastian hukum atas kepemilikan tanah bagi seseorang ialah dengan dilakukannya suatu pendaftaran hak atas tanah sebagaimana rumusan Pasal 19 Ayat 1 Undang-Undang Nomor 5 Tahun 1960 tentang peraturan dasar Pokokpokok Agraria. Adanya kepastian hukum hak-hak atas tanah bagi setiap orang secara tegas dinyatakan dalam Pasal 19 ayat 1 bahwa untuk menjamin kepastian hukum oleh Pemerintah diadakan pendaftaran tanah di seluruh wilayah Republik Indonesia yang disempurnakan dalam Peraturan Pemerintah Nomor 24 Tahun 1997 tentang Pendaftara Tanah. Indonesia sebagai Negara hukum berkepentingan mengatur perlindungan hukum terhadap

\footnotetext{
${ }^{22}$ Boedi Harsono, Hukum Agraria Indonesia, Sejarah ... Op. Cit., Hal.. 25.

${ }^{23}$ Badan Pertanahan Nasional, Laporan Kinerja Instansi Pemerintah Tahun Anggaran 2012, (Jakarta: BPN RI, 2013), Hal.. 1.

${ }^{24}$ Achmad Rubaie, Hukum Pengadaan Tanah Untuk Kepentingan Umum, (Malang: Bayumedia, 2007), Hal.. 1.

${ }^{25}$ Florianus SP Sangsung, Tata Cara Mengurus...Op. Cit., Hal.. 2.

${ }^{26}$ Ibid, Hal. 18.

${ }^{27}$ Muhammad Yamin Lubis dan Abdul Rahim Lubis, Hukum Pendaftaran Tanah, (Bandung: Mandar Maju, 2008), Hal.. 237.
} 
pemegang sertifikat hak atas tanah yang berkepastian hukum, bermanfaat, dan berkeadilan dengan cara merespon kebutuhan serta keinginan pemegang hak atas tanah dalam kehidupan masyarakat secara transparan, tanpa tipu daya, intimidasi atau diskriminasi, dimana semua orang ialah sama di hadapan hukum dan atas perlindungan hukum yang sama tanpa diskriminasi apapun. ${ }^{28}$

Hak-hak subyek hukum atas suatu bidang tanah dengan alat bukti berupa suatu sertipikat harus dilindungi mengingat sertifikat hak atas tanah merupakan bukti tertulis yang dibuat oleh Pejabat Umum yang berwenang, oleh karenanya menurut Pasal 164 HIR dan Pasal 1866 KUHPerdata merupakan bukti otentik yang memiliki kekuatan pembuktian sempurna, dalam Pasal 32 ayat (2) Peraturan Pemerintah Nomor 24 Tahun 1997 ditentukan dengan tegas bahwa sertipikat merupakan Surat tanda bukti hak yang berlaku sebagai alat pembuktian yang kuat.

Suatu sertifikat hak atas tanah dapat digugat oleh pihak lain yang berkepentingan yang merasa dirinya dirugikan. Dalam hal sertifikat ganda hak atas tanah, maka akan timbul suatu tumpang tindih dan ketidakpastian mengenai siapakah yang berhak untuk memegang hak atas tanah. Dengan demikian harus ada bentuk perlindungan hukum agar menjadi pasti siapa sebenarnya pemegang yang sah suatu hak atas tanah yang telah disertifikasikan.

Perlindungan hukum yang dapat diberikan bisa secara preventif dan secara represif yang meliputi :

1. Dalam ketentuan Pasal 32 ayat (2) Peraturan Pemerintah Nomor 24 Tahun 1997 tentang Pendaftaran Tanah telah memberikan perlindungan, dimana seseorang yang tercantum namanya dalam sertifikat tidak dapat diajukan gugatan oleh pihak lain yang mempunyai hak atas tanah setelah 5 tahun dan statusnya sebagai pemilik hak atas tanah akan terus dilindungi sepanjang tanah itu diperoleh dengan itikad baik dan dikuasai secara nyata oleh pemegang hak yang bersangkutan. ${ }^{29}$

2. Peran hakim sangat dibutuhkan dalam memeriksa dan memastikan kebenaran dari keterangan dalam sertifikat. Hakim harus membuktikan, meneliti dan memeriksa asal-usul sertifikat. ${ }^{30}$ Harus diselidiki bahwa orang yang mengajukan pendaftaran hak atas tanah memang berhak atas tanah tersebut, maksudnya bahwa ia memperoleh hak atas tanah secara sah dari pihak yang berwenang yang mengalihkan hak atas tanahnya, dan kebenaran dari keterangan lainnya yang tercantum dalam sertifikat. Sehingga nantinya dapat ditentukan siapa pemegang sah hak atas tanah dan ia bisa mendapatkan kepastian hukum dari kepemilikan sertifikat hak atas tanah tersebut.

Pada umumnya, sertifikat hak atas tanah diterbitkan sebagai suatu wujud bukti kepemilikan hak atas tanah. Sertifikat hak atas tanah juga memiliki fungsi sebagai alat pembuktian yang kuat atas kepemilikan hak atas tanah. Hal ini telah ditentukan dalam Pasal 19 ayat (2) huruf c Undang-Undang Pokok Agraria secara implisit. Dikatakan secara implisit karena ketentuan tersebut hanya mengatur bahwa sebagai proses akhir dari pendaftaran tanah yaitu pemberian surat-surat tanda bukti hak, yang berlaku sebagai alat pembuktian yang kuat. Jadi dalam ketentuan tersebut tidaklah menyebutkan sertifikat tanah sebagai surat tanda bukti hak secara langsung. Setelah berlakunya Peraturan Pemerintah Nomor 10 Tahun 1961 tentang Pendaftaran Tanah yang diganti dengan Peraturan Pemerintah Nomor 24 Tahun 1997 tentang Pendaftaran Tanah, tepatnya pada Pasal 13 ayat (3) menentukan bahwa surat tanda bukti hak atas tanah yang didaftar dinamakan sertifikat.

Dalam ketentuan Pasal 32 ayat (1) Peraturan Pemerintah Nomor 24 Tahun 1997 tentang Pendaftaran Tanah menentukan bahwa, "Sertipikat merupakan surat tanda bukti hak yang berlaku sebagai alat pembuktian yang kuat mengenai data fisik dan data yuridis yang termuat di dalamnya, sepanjang data fisik dan data yuridis tersebut sesuai dengan data yang ada dalam surat ukur dan buku tanah yang bersangkutan." Hal ini berarti bahwa data fisik, yang meliputi keterangan mengenai letak, batas dan luas tanah serta data yuridis yang meliputi keterangan mengenai status hukum bidang tanah, pemegang haknya dan hak pihak lain serta beban-beban lain yang membebani tanag tersebut, yang tercantum dalam sertifikat mempunyai kekuatan hukum dan harus diterima hakim sebagai keterangan yang benar selama dan sepanjang tidak ada bukti lain yang membuktikan sebaliknya. ${ }^{31}$

Dalam penjelasan Peraturan Pemerintah Nomor 24 Tahun 1997 tentang Pendaftaran Tanah ditegaskan bahwa dalam pendaftaran tanah di Indonesia menganut sistem publikasi negatif, namun juga mengandung unsur sistem positif. Stelsel positif dituangkan dalam hal adanya campur tangan Pejabat Pembuat Akta Tanah dan kantor Pertanahan terhadap peralihan-peralihan hak atas tanah yang memberikan jaminan bahwa nama orang yang terdaftar benar-benar yang berhak tanpa menutup kesempatan kepada yang berhak sebenarnya untuk masih dapat membelanya. ${ }^{32}$ Jadi, walaupun sertifikat merupakan alat bukti yang kuat, namun keabsahannya tetap dapat digugat oleh pihak lain dengan didukung oleh bukti-bukti yang kuat yang dapat membuktikan sebaliknya.

Dalam hal adanya dua sertifikat atas sebidang tanah atau sertifikat ganda, maka ada kemungkinan bahwa kedua sertifikat tersebut sama-sama memiliki kekuatan yang sah menurut undang-undang. Sehingga dalam hal ini, hanya hakim lah yang dapat memutus pihak mana yang berhak atas hak atas tanah dari salah satu pihak yang memegang sertifikat ganda yang bersangkutan. Namun, kewenangan hakim dalam menentukan pemegang sah hak atas tanah dengan adanya sertifikat ganda dapat menimbulkan putusan disparitas sehingga dapat menimbulkan kecemburuan antara pemegang sertifikat ganda hak atas tanah. Sebagai alat pembuktian yang kuat, maka sertifikat harus menjamin kepastian hukum mengenai orang yang menjadi pemegang

${ }^{28}$ Urip Santoso, Hukum Agraria: Kajian Komprehensif, (Jakarta: Kencana Prenadamedia Group, 2012), Hal.. 29

${ }^{29}$ Adrian Sutedi, Sertifikat Hak Atas Tanah, (Jakarta: Sinar Grafika, 2014), Hal.. 194.

${ }^{30}$ Ibid., hlm. 13.

${ }^{31}$ Urip Santoso, Hukum Agraria:.. Op. Cit., hlm. 318-319.

${ }^{32}$ Adrian Sutedi, Sertifikat Hak.. Op.Cit., hlm. 103. 
hak milik atas tanah, kepastian hukum mengenai lokasi dari tanah, batas serta luas bidang tanah, dan kepastian hukum mengenai hak atas tanah miliknya. ${ }^{33}$

Menurut Maria S.W. Sumardjono bahwa hukum menghendaki kepastian. Hukum Pertanahan Indonesia menginginkan kepastian siapa pemegang hak milik atau hak-hak lain atas sebidang tanah. Di dalam realitasnya, pemegang sertifikat atas tanah belum merasa aman akan kepastian haknya, bahkan sikap keraguraguan yang seringkali muncul dengan banyaknya gugatan yang menuntut pembatalan sertifikat tanah melalui pengadilan, ${ }^{34}$ dan menurut Muchtar Wahid, berpendapat bahwa sertifikat tanah sebagai produk pendaftaran yang memenuhi aturan hukum normatif, belum menjamin kepastian hukum dari sudut pandang sosiologi hukum, ${ }^{35}$ yang dimaksud oleh beliau kepastian hukum dari sudut pandang sosiologi hukum itu ialah realitas sosial yang terjadi di masyarakat, dengan memperhatikan kemampuan pemerintah, maka pelaksanaan pendaftaran tanah dilakukan secara bertahap.

Sebagai langkah awal dilakukan pengukuran desa demi desa untuk memenuhi ketersediaan peta dasar pendaftaran tanah yang memuat titik - titik dasar tehnik dan unsur-unsur geografis serta batas fiksik bidang-bidang tanah, pada wilayah yang belum dilakukan secara sistematik, peta dasar pendaftraan tanah sangat diperlukan untuk mengidentifikasi dan menentapkan letak tanah yang akan didaftarkan secara sporadik, dan selanjutnya menjadi dasar untuk pembuatan peta pendaftaran. Sehubungan dengan pemberian kepastian hukum mengenai hak-hak atas tanah, baik mengenai subjek maupun objeknya, maka pemerintah mengharuskan dilakukan pengumuman mengenai hak -hak atas tanah, yang meliputi :

1. Pengumuman mengenai subjek yang menjadi pemegang hak yang dikenal dengan sebagai asas publisitas dengan maksud agar masyarakat luas dapat mengetahui tentang subjek dan objek atas satu bidang tanah. Adapun implementasi dari asas publisitas ini yaitu dengan mengadakan pendaftaran tanah.

2. Penetapan mengenai letak, batas-batas, dan luas bidang-bidang tanah yang dipunyai seseorang atas sesuatu hak atas tanah, dikenal sebagai asas spesialitas dan implementasinya ialah dengan mengadakan Kadaster, dengan demikian, maka seseorang yang hendak membeli suatu hak atas tanah tidak perlu melakukan penyelidikan sendiri, karena keterangan mengenai subyek dan objek atas suaru bidang tanah dapat diperoleh dengan mudah pada instansi pemerintah yang ditugaskan menyelenggarakan Pendaftaran Tanah.

\section{KESIMPULAN DAN SARAN}

Berdasarkan kajian yang telah diuraikan, berikut disajikan kesimpulan yang merupakan jawaban terhadap permasalahan yang telah dibahas: Pertama, kepastian Hukum Sertifikat Hak Milik Atas Tanah Dalam Hukum Pertanahan Indonesia adalah belum sesuai dengan kepastian hokum mengenai objek hak atas tanah, subjek hak atas tanah dan mengenai kepastian atas tanah dan dengan jaminan negara ini diberikan kepada pemilik atau pemegang sertifikat dapat diberikan karena tanahnya sudah terdaftar dalam sistem administrasi pertanahan negara. Kedua, sengketa kepemilikan tanah baik secara yuridis dan secara sosiologis, serta tidak Idealnya kepemilikan tanah agar memiliki kepastian hukum yang sesuai adalah perlindungan bagi pemegang hak atas tanah yang secara yuridis formal merupakan hak bagi setiap warga negara Indonesia, namun demikian tindakan untuk menindak setiap pihak yang melakukan pendudukan atas tanah oleh pihak tertentu secara tidak sah harus dilakukan dengan hatihati agar tidak menimbulkan konflik sosial, ataupun konflik antara warga dengan Pemerintah. Pemegang sertifikat hak atas tanah, karena dengan dilakukannya pendaftaran tanah berarti akan tercipta kepastian hukum, kepastian hak serta tertib administrasi pertanahan sehingga semua pihak terlidungi dengan baik, baik pemegang sertifikat, pemegang hak atas tanah, pihak ketiga yang memperoleh hak atas tanah maupun pemerintah sebagai penyelenggara Negara.

\section{DAFTAR PUSTAKA}

A.P.Parlindungan, Pedoman Pelaksana UUPA dan Tatacara PPAT, (Bandung: Alumni Bandung, 1987)

Wayan Suandra, Hukum Pertanahan Indonesia, (Jakarta: Rienika Cipta, 1991)

Soedikno Mertokusumo, Hukum dan Politik Agraria, (Jakarta: Karunika, 1988)

Boedi Harsono, Hukum Agraria Indonesia Himpunan Peraturan-Peraturan Hukum Tanah, (Jakarta: Djambatan, 2002)

Suhariningsih, Tanah terlantar, (Jakarta: Prestasi Pustaka Publisher, 2009)

A.P. Parlindungan, Kumpulan Tulisan Tentang Hukum Tanah, Cetakan I, (Bandung: Alumni, 1993)

Peter Mahmud Marzuku, Penelitain Hukum, Cetakan Ke- 11, (Jakarta: Kencana, 2011)

Muchtar Wahid, Memaknai Kepastian Hukum Hak Milik Atas Tanah: Suatu Analisis dengan Pendekatan Terpadu Secara Normatif dan Sosiologi, (Jakarta: Republika, 2008)

Arie Sukanti Hutagalung, dkk, Hukum Pertanahan di Belanda dan Indonesia, (Denpasar: Pustaka Larasan, 2012)

\footnotetext{
${ }^{33}$ Ibid, hlm. 11

${ }^{34}$ Soemarjono, Maria S.W., Kebijakan Pertanahan Antara Regulasi \& Implementasi, (Jakarta: Kompas, 2001$)$, Hal.. 18.

${ }^{35}$ Muchtar Wahid, Memaknai Kepastian Hukum Hak Milik Atas Tanah: Suatu Analisis dengan Pendekatan Terpadu Secara Normatif dan Sosiologi, (Jakarta: Republika, 2008), Hal.. 22.
} 
Website : http://yustisia.unmermadiun.ac.id/index.php/yustisia

Boedi Harsono, Hukum Agraria Indonesia, Sejarah Pembentukan UUPA, Isi dan Pelaksanaannya. Jilid I: Hukum Tanah Nasional, (Jakarta: Djambatan, 2003)

Parlindungan, AP, Pendaftaran Tanah di Indonesia (Berdasarkan PP No. 24 Tahun 1997), (Bandung: Mandar Maju, 2009)

Florianus SP Sangsung, Tata Cara Mengurus Sertifikat Tanah, (Jakarta: Visimedia, 2007)

Sudantoko, Djoko dan Hamdani, Muliawan, Dasar-Dasar Pengantar Ekonomi Pembangunan, (Jakarta: PT PP Mardi Mulya, 2009)

Mochtar Kusumaatmadja, Fungsi Hukum dan Perkembangan Hukum Dalam Pembangunan Nasional, (Bandung: Bina Cipta, 1976)

Badan Pertanahan Nasional, Laporan Kinerja Instansi Pemerintah Tahun Anggaran 2012, (Jakarta: BPN RI, 2013)

Achmad Rubaie, Hukum Pengadaan Tanah Untuk Kepentingan Umum, (Malang: Bayumedia, 2007)

Muhammad Yamin Lubis dan Abdul Rahim Lubis, Hukum Pendaftaran Tanah, (Bandung: Mandar Maju, 2008)

Urip Santoso, Hukum Agraria: Kajian Komprehensif, (Jakarta: Kencana Prenadamedia Group, 2012)

Adrian Sutedi, Sertifikat Hak Atas Tanah, (Jakarta: Sinar Grafika, 2014)

Soemarjono, Maria S.W., Kebijakan Pertanahan Antara Regulasi \& Implementasi, (Jakarta: Kompas, 2001)

Muchtar Wahid, Memaknai Kepastian Hukum Hak Milik Atas Tanah: Suatu Analisis dengan Pendekatan Terpadu Secara Normatif dan Sosiologi, (Jakarta: Republika, 2008) 